\title{
Wide and High Additive Manufacturing (WHAM)
}
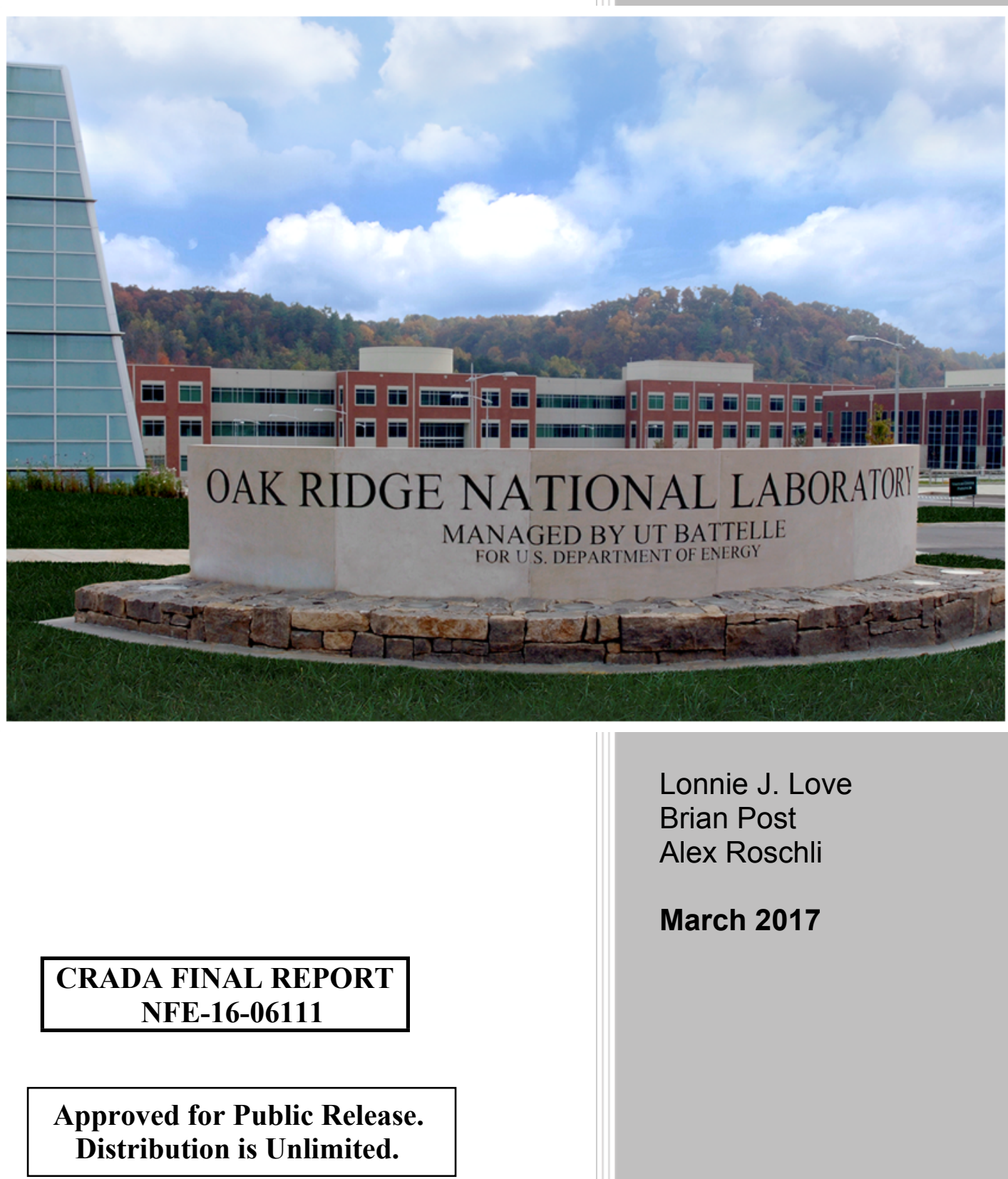

Lonnie J. Love

Brian Post

Alex Roschli

March 2017 


\section{DOCUMENT AVAILABILITY}

Reports produced after January 1, 1996, are generally available free via US Department of Energy (DOE) SciTech Connect.

Website http://www.osti.gov/scitech/

Reports produced before January 1, 1996, may be purchased by members of the public from the following source:

National Technical Information Service
5285 Port Royal Road
Springfield, VA 22161
Telephone 703-605-6000 (1-800-553-6847)
TDD 703-487-4639
Fax 703-605-6900
E-mail info@ntis.gov
Website http://www.ntis.gov/help/ordermethods.aspx

Reports are available to DOE employees, DOE contractors, Energy Technology Data Exchange representatives, and International Nuclear Information System representatives from the following source:

Office of Scientific and Technical Information

PO Box 62

Oak Ridge, TN 37831

Telephone 865-576-8401

Fax 865-576-5728

E-mail reports@osti.gov

Website http://www.osti.gov/contact.html

This report was prepared as an account of work sponsored by an agency of the United States Government. Neither the United States Government nor any agency thereof, nor any of their employees, makes any warranty, express or implied, or assumes any legal liability or responsibility for the accuracy, completeness, or usefulness of any information, apparatus, product, or process disclosed, or represents that its use would not infringe privately owned rights. Reference herein to any specific commercial product, process, or service by trade name, trademark, manufacturer, or otherwise, does not necessarily constitute or imply its endorsement, recommendation, or favoring by the United States Government or any agency thereof. The views and opinions of authors expressed herein do not necessarily state or reflect those of the United States Government or any agency thereof. 
ORNL/TM-2017/167

CRADA/NFE-16-06111

Energy and Transportation Sciences Division

Advanced Manufacturing Office

\title{
Wide and High Area Additive Manufacturing (WHAAM)
}

\author{
Authors \\ Lonnie J. Love, Ph.D. \\ Brian Post, Ph.D. \\ Alex Roschli
}

Date Published:

March 2017

\author{
Prepared by \\ OAK RIDGE NATIONAL LABORATORY \\ Oak Ridge, Tennessee 37831-6283 \\ managed by \\ UT-BATTELLE, LLC \\ for the \\ US DEPARTMENT OF ENERGY \\ under contract DE-AC05-00OR22725
}

Approved For Public Release 



\section{CONTENTS}

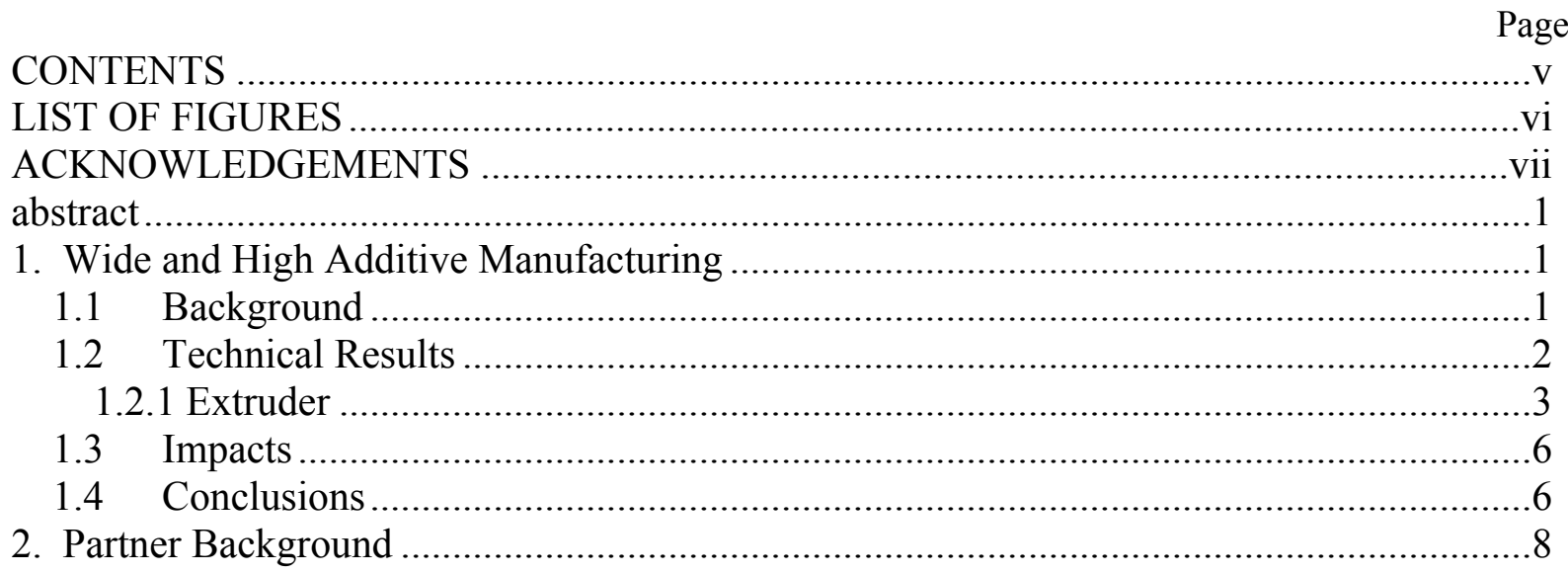




\section{LIST OF FIGURES}

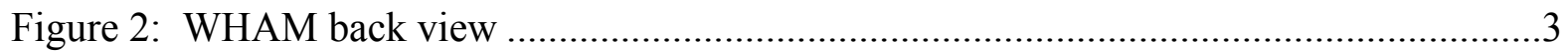

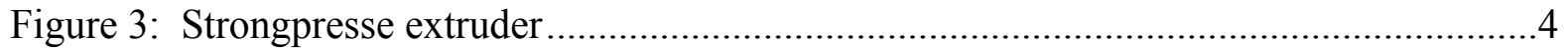

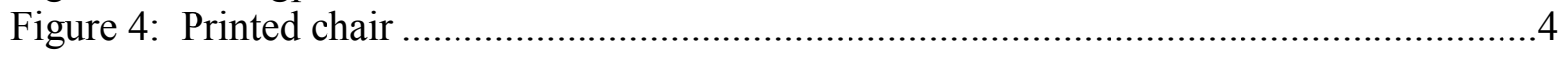

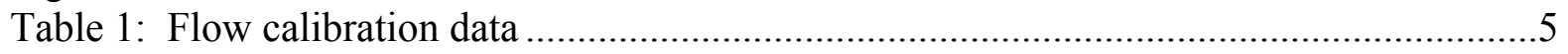

Figure 5: Flow rate.....................................................................................................

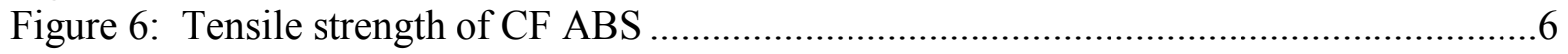

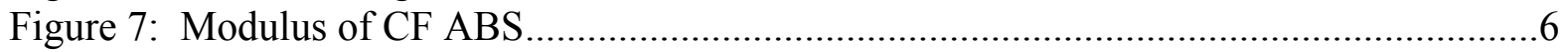




\section{ACKNOWLEDGEMENTS}

This CRADA NFE-16-06111 was conducted as a Technical Collaboration project within the Oak Ridge National Laboratory (ORNL) Manufacturing Demonstration Facility (MDF) sponsored by the US Department of Energy Advanced Manufacturing Office (CPS Agreement Number 24761).

Opportunities for MDF technical collaborations are listed in the announcement "Manufacturing Demonstration Facility Technology Collaborations for US Manufacturers in Advanced

Manufacturing and Materials Technologies" posted at http:/web.ornl.gov/sci/manufacturing/docs/FBO-ORNL-MDF-2013-2.pdf. The goal of technical collaborations is to engage industry partners to participate in short-term, collaborative projects within the Manufacturing Demonstration Facility (MDF) to assess applicability and of new energy efficient manufacturing technologies. Research sponsored by the U.S. Department of Energy, Office of Energy Efficiency and Renewable Energy, Advanced Manufacturing Office, under contract DE-AC0500OR22725 with UT-Battelle, LLC. 


\begin{abstract}
The goal of this project is to develop and demonstrate the enabling technologies for Wide and High Additive Manufacturing (WHAM). WHAM will open up new areas of U.S. manufacturing for very large tooling in support of the transportation and energy industries, significantly reducing cost and lead time. As with Big Area Additive Manufacturing (BAAM), the initial focus is on the deposition of composite materials.
\end{abstract}

\title{
1. WIDE AND HIGH ADDITIVE MANUFACTURING
}

This phase 1 technical collaboration project (MDF-TC-2017-167) was begun on August 2016 and was completed on March 2017. The collaboration partner Ingersoll Machine Tools is a small business. One sentence to summarize results.

\subsection{BACKGROUND}

Ingersoll Machine Tool is a small U.S. machine tool manufacturer located in Rockford, Illinois that produces large scale machine tools for use in metal cutting and automated fiber placement. The company was founded in 1891 by Winthrop Ingersoll when he moved W.R. Eynon \& Co. from Cleveland, Ohio to Rockford. Originally, Ingersoll Machine Tools focused almost entirely on milling machinery and processes for metal removal. It acquired contracts from General Electric and, by 1917, was closely involved with wartime production and had a workforce of 600 . It went on to produce customized machines for industries such as airplane and auto manufacturing. In the period from the 1960 s to the $1980 \mathrm{~s}$, the company employed around 2,000 people at its plant, also developing CNC technologies to introduce automation into its manufacturing processes. Today, Ingersoll is a global leader in the development of advanced machine tools for the world's aerospace, transportation, energy, and other heavy industries. Products range from general purpose machines that bring greater flexibility and productive to a wide variety of parts, to special purpose, one-of-a-kind machines delivering unique solutions. For the aerospace industry, Ingersoll excels in building machines to produce component parts and large structures made of aluminum, hard metals and composite materials. In addition, Ingersoll provides a unique contract manufacturing resource for prototype machining and production runs, from small engine parts to locomotive diesel blocks and windmill hubs.

The goal of this project is to develop and demonstrate the enabling technologies for Wide and High Additive Manufacturing (WHAM). WHAM will open up new areas of U.S. manufacturing for very large tooling in support of the transportation and energy industries, significantly reducing cost and lead time. As with Big Area Additive Manufacturing (BAAM), the initial focus is on the deposition of composite materials. This effort compliments Ingersoll's expertise in the composites industry where they are a world leader in tape layup technology. The systems they typically develop are extremely large (exceeding $100 \mathrm{ft}$ ) for the wind, rail, shipping and aerospace industry. WHAM will enable Ingersoll to rapidly manufacture large tooling to help accelerate U.S. manufacturing in the area of large scale components (major dimensions exceeding $20 \mathrm{ft}$ ). The primary technical challenge is controlling part distortion and delamination due to the very large part sizes. The approach the team is exploring is to use two complimentary technologies. First, prior experience shows that layer adhesion is a function of the layer temperature during deposition. A typical layer could exceed 1000 square feet with a bead thickness of 0.1 " which is equivalent to $500 \mathrm{lbs}$ of material. This will require 
approximately five hours to print with current BAAM technologies. Current efforts show that ideal layer times need to be less than 30 minutes for good adhesion. Therefore, an extruder with approximately $1000 \mathrm{lb} / \mathrm{hr}$ is needed for WHAM. The second technology is localized heating to eliminate the need for a heated bed. Ingersoll has extensive experience in the area of IR heating for composites and leveraged this experience to address initial layer adhesion. The goal of the first phase is to install a current $100 \mathrm{lb} / \mathrm{hr}$ extruder on an Ingersoll system and demonstrate the ability to control and deposit material with localized heating.

\subsection{TECHNICAL RESULTS}

The goal of the project is to manufacture a large scale composite additive manufacturing system. Figure 1 and Figure 2 are a conceptual design of the WHAM. The system will be based on an existing Ingersoll gantry design. The system is large enough that the $1000 \mathrm{lb} / \mathrm{hr}$ extruder can be directly mounted on the gantry as well as multiple $1000 \mathrm{lb}$ hoppers for drying the material. Four 1000 $\mathrm{lb}$ hoppers will provide 4 hours of residence time for the material to dry when operating at $1000 \mathrm{lb} / \mathrm{hr}$. When one hopper is emptied, the system can automatically switch to a different hopper and park in a corner to quickly replenish the empty hopper. As with other Ingersoll gantry systems, multiple tools can be changed to enable additive, subtractive, pick and place as well as tape placement. The development of new materials such as foams and long fiber reinforcement will enable direct structural part production.

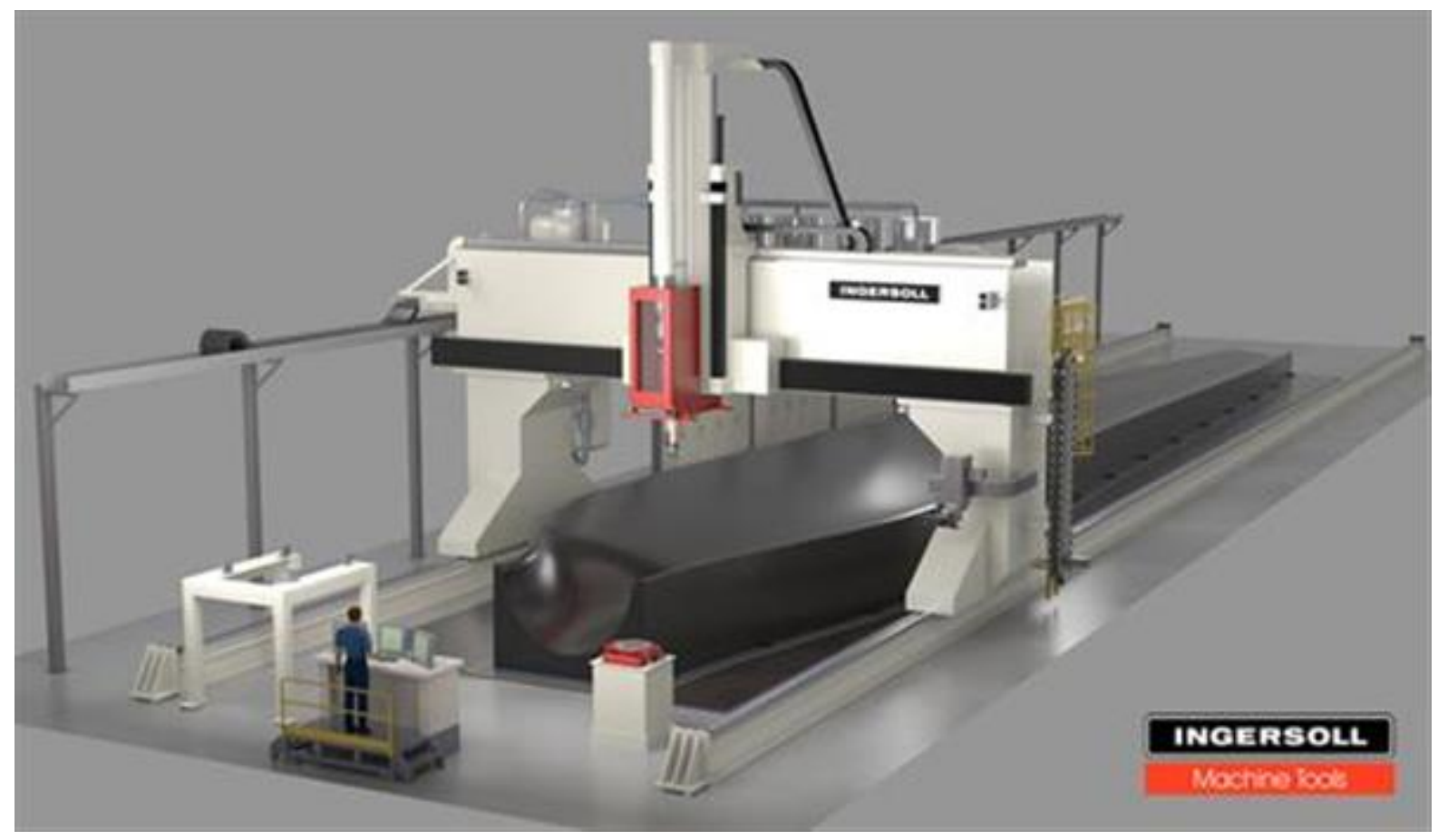

Figure 1: WHAM front view 


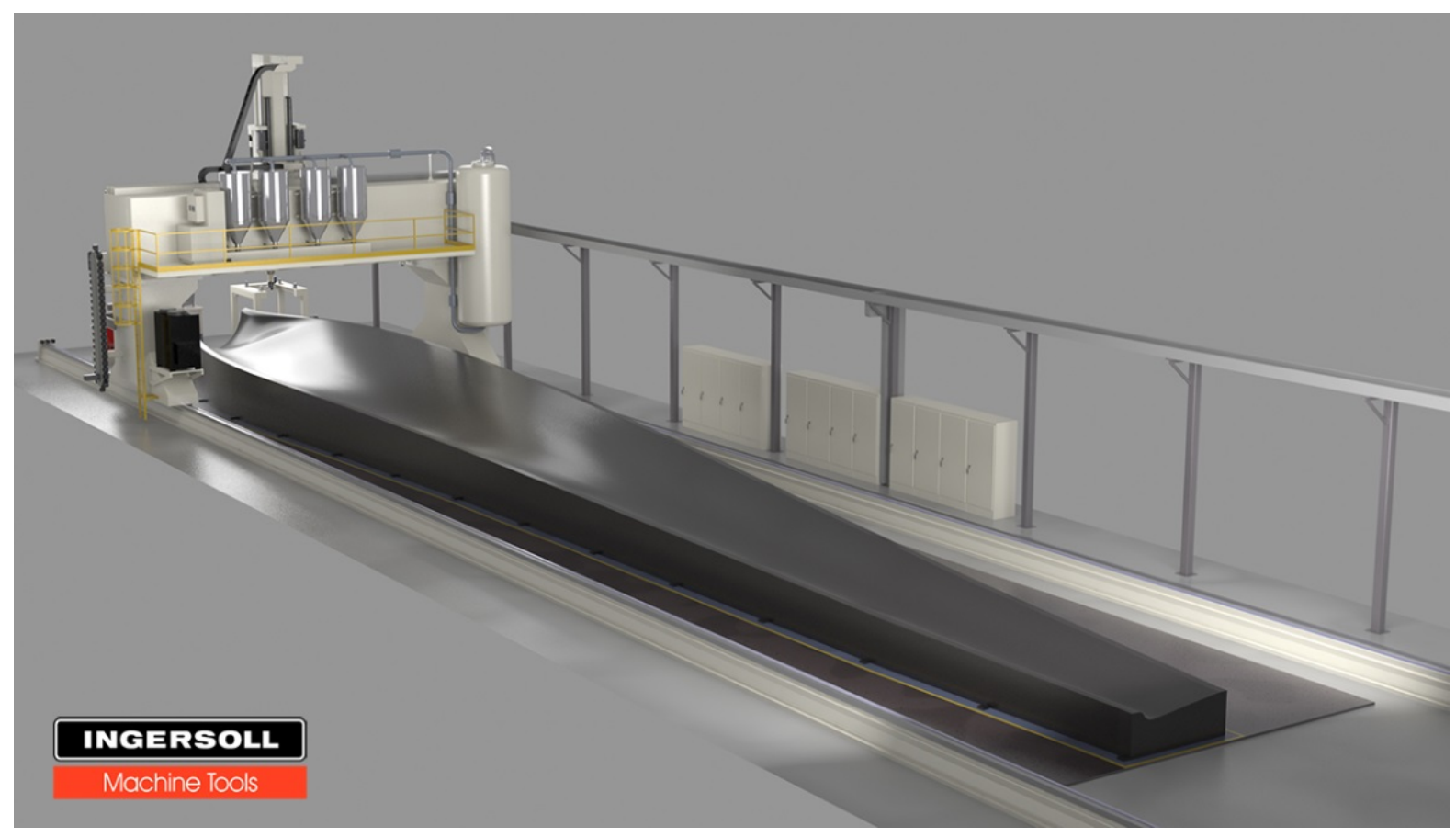

Figure 2: WHAM back view

\subsubsection{Extruder}

In order to accelerate the project, ONRL leveraged a current technical collaboration with Strangpresse. Under this technical collaboration, Strangpresse had developed a new $150 \mathrm{lb} / \mathrm{hr}$ extruder (see Figure 3). Ingersoll installed the extruder on a testbed at their Rockford facility and integrated all controls. ORNL visited the facility and installed the ORNL slicer and developed both a translator for the g-code for the robot and identified all of the required processing parameters. The system is completely operational (see Figure 4). 


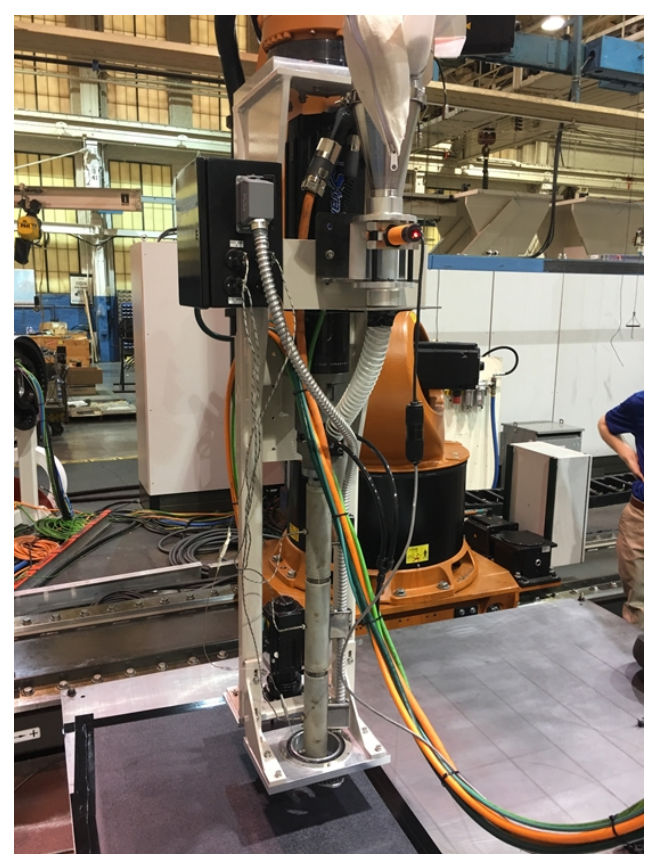

Figure 3: Strangpresse extruder

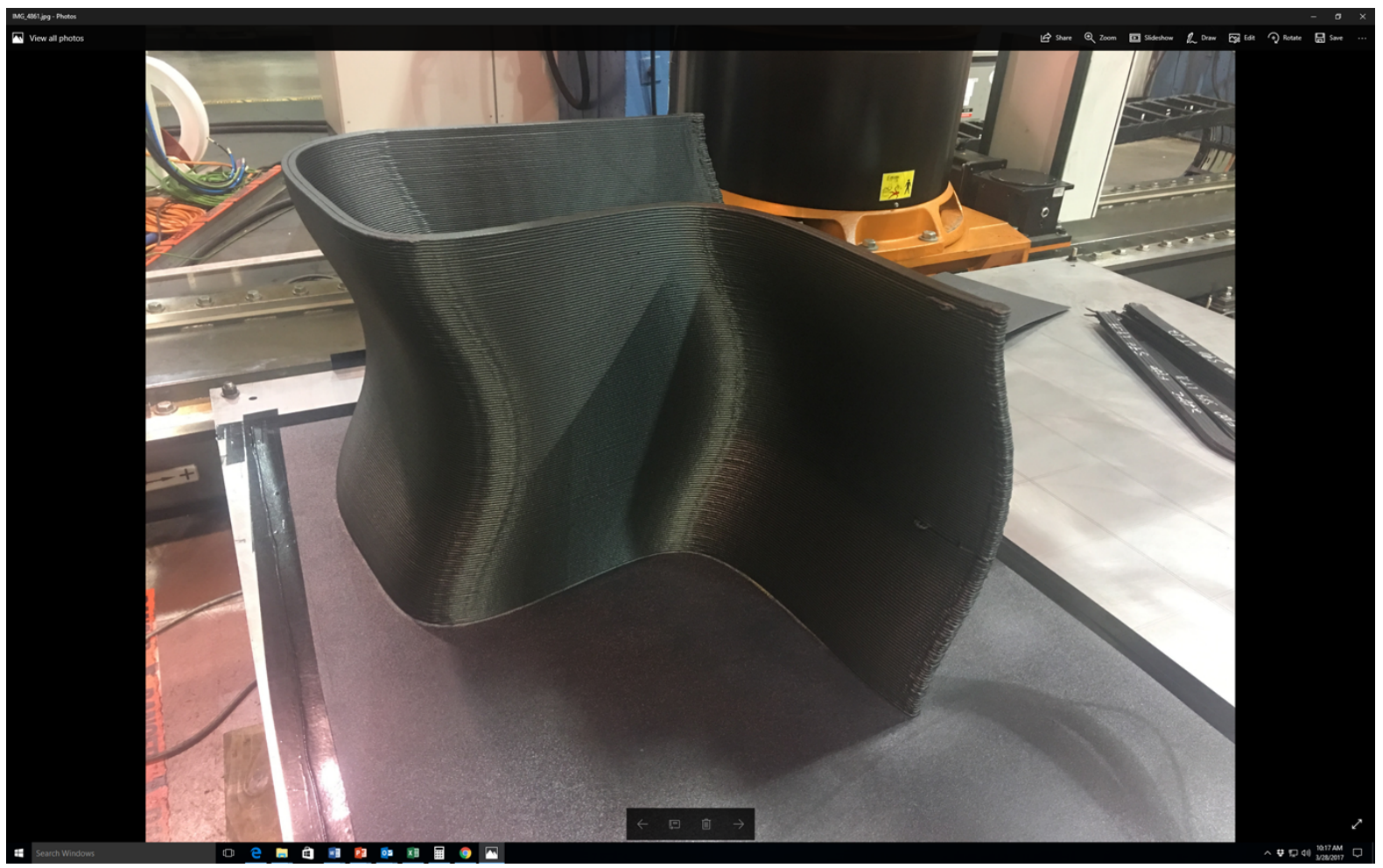

Figure 4: Printed chair 
Figure 5 and Table 1 provide the resultant flow rate characteristics of the extruder.

Table 1: Flow calibration data

\begin{tabular}{|cccc|}
\hline RPM & Ib of material & Ib/min & Ib/hour \\
\hline 200 & 0.25 & 0.25 & 15 \\
500 & 0.6875 & 0.6875 & 41.25 \\
800 & 1.0625 & 1.0625 & 63.75 \\
2500 & 2.5 & 2.5 & 150 \\
\hline
\end{tabular}

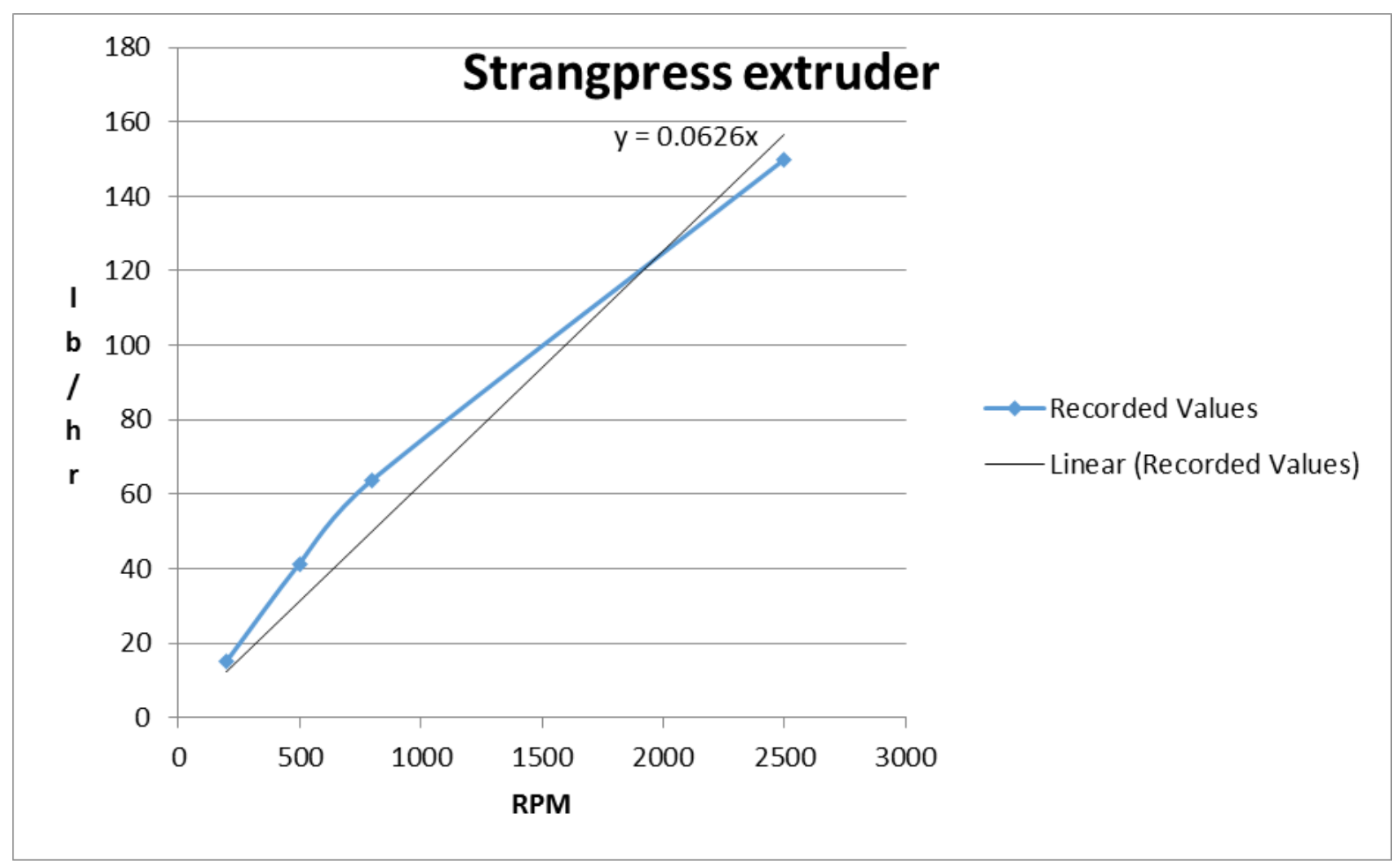

Figure 5: Flow rate

Figure 6 and Figure 7 show the resulting mechanical properties of the parts manufactured on the WHAM at Rockford. 


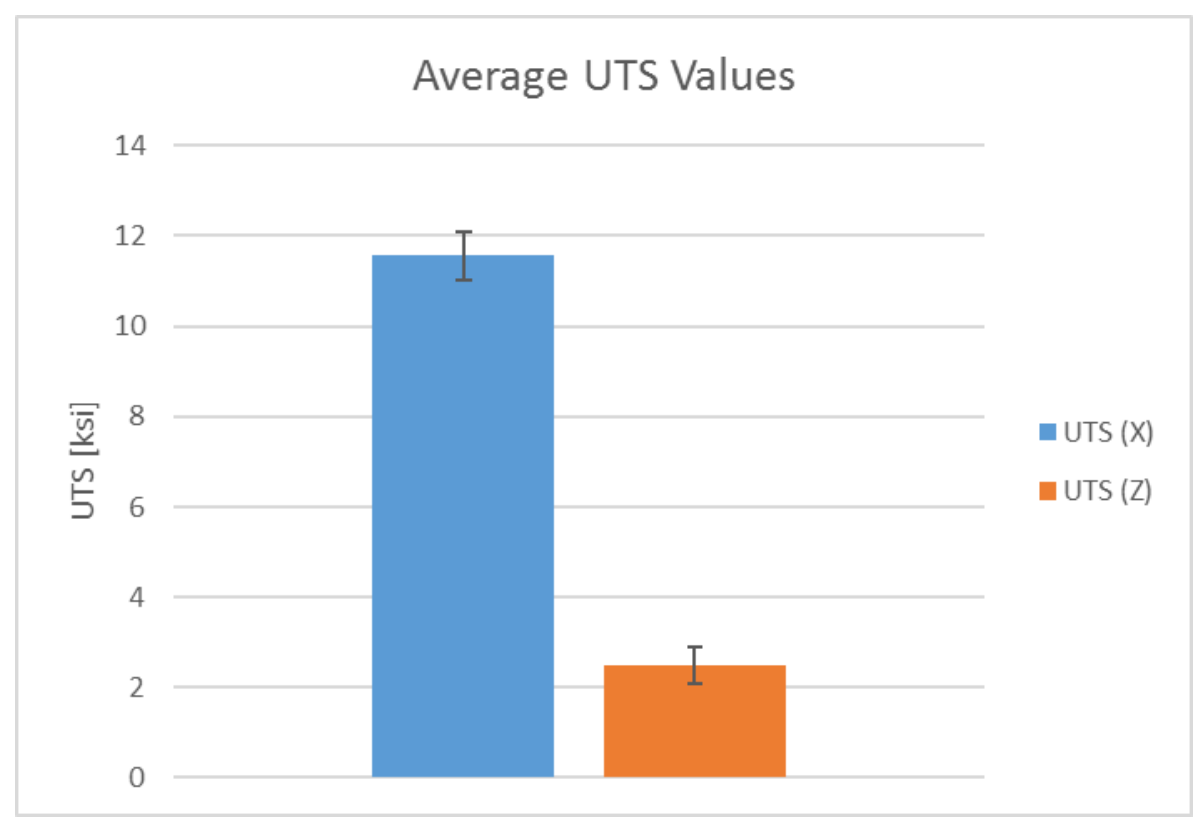

Figure 6: Tensile strength of CF ABS

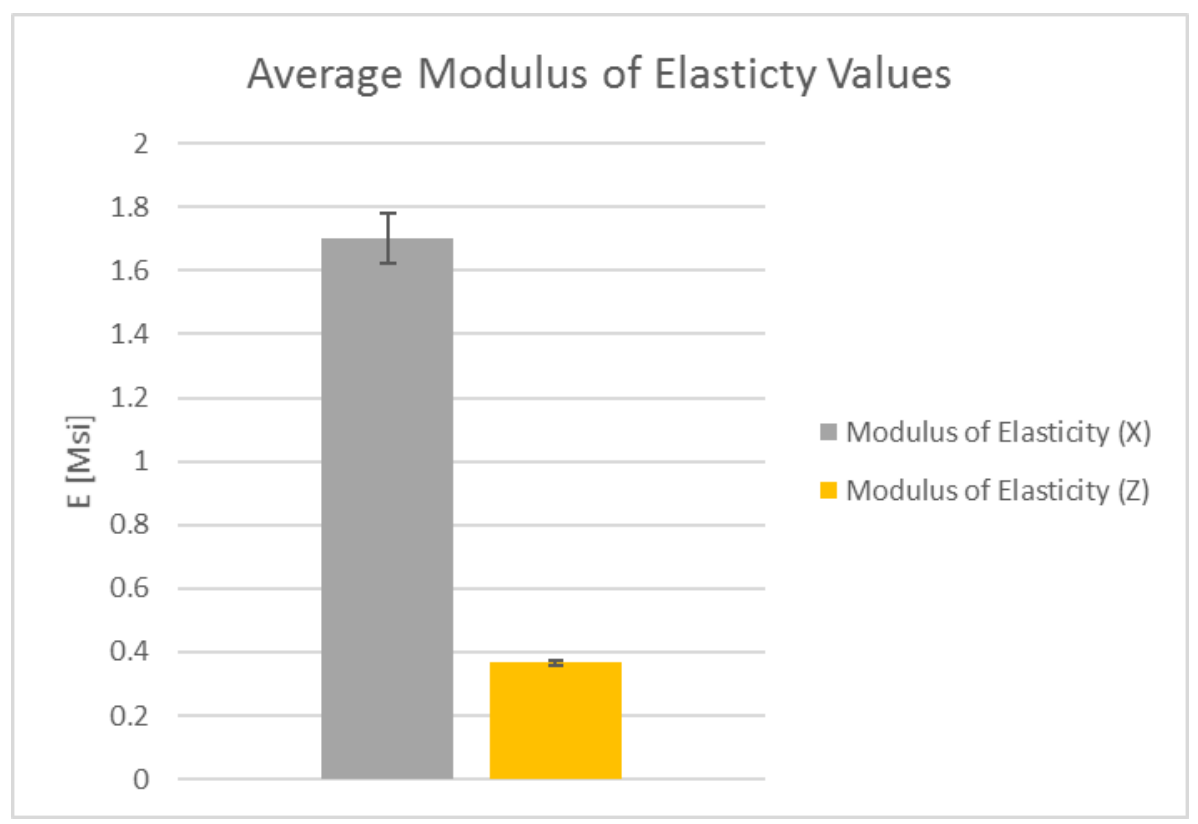

Figure 7: Modulus of CF ABS

\subsection{IMPACTS}

The development of WHAM will enable greater innovation in the areas of U.S. large scale manufacturing which includes marine, rail, trucks, aerospace and energy (wind, hydro, solar). The technology is scalable to allow rapid manufacture of very large structures at a relatively fast rate and low cost. 


\subsection{CONCLUSIONS}

The goal of this project was to identify the system requirements, design an extruder, design a heated platform and develop the interfaces between the extruder and Ingersoll gantry system. The team successfully identified the system requirements by specifying the need for a $1000 \mathrm{lb} / \mathrm{hr}$ extruder. The team originally designed a series of extruders (ten $100 \mathrm{lb} / \mathrm{hr}$ extruders) but elected to go with a single large $1000 \mathrm{lb} / \mathrm{hr}$ extruder. Furthermore, the team successfully evaluated an existing $150 \mathrm{lb} / \mathrm{hr}$ extruder from Strangpresse on an Ingersoll testbed. The results provide the team confidence that Strangpresse can design and manufacture the final $1000 \mathrm{lb} / \mathrm{hr}$ extruder. ORNL developed the processing parameters and slicing software successfully demonstrating pellet to part manufacturing on an Ingersoll testbed. Ingersoll installed a bank of infrared heaters and used that to locally heat the start sheet rather than designing a full heated table. Test pieces were manufactured and evaluated successfully.

This provides the team with confidence that Phase 2 efforts can likewise be based on aligning both Ingersoll and Strangpresse. We propose to align the second phase of both projects. Strangpresse will design and fabricate the extruder with ORNL working with Ingersoll on the integration and control of the extruder on an Ingersoll gantry. This will also foster commercialization of Strangpresse and Ingersoll within the same project. 


\section{PARTNER BACKGROUND}

Ingersoll Machine Tool is a U.S. manufacturer located in Rockford, Illinois that produces large scale machine tools for use in metal cutting and automated fiber placement. The company was founded in 1891 by Winthrop Ingersoll when he moved W.R. Eynon \& Co. from Cleveland, Ohio to Rockford. Originally, Ingersoll Machine Tools focused almost entirely on milling machinery and processes for metal removal. It acquired contracts from General Electric and, by 1917, was closely involved with wartime production and had a workforce of 600. It went on to produce customized machines for industries such as airplane and auto manufacturing. In the period from the 1960s to the 1980s, the company employed around 2,000 people at its plant, also developing $\mathrm{CNC}$ technologies to introduce automation into its manufacturing processes. Today, Ingersoll is a global leader in the development of advanced machine tools for the world's aerospace, transportation, energy, and other heavy industries. Products range from general purpose machines that bring greater flexibility and productive to a wide variety of parts, to special purpose, one-of-a-kind machines delivering unique solutions. For the aerospace industry, Ingersoll excels in building machines to produce component parts and large structures made of aluminum, hard metals and composite materials. In addition, Ingersoll provides a unique contract manufacturing resource for prototype machining and production runs, from small engine parts to locomotive diesel blocks and windmill hubs. 